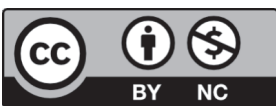

\title{
O CONCEITO DE PESSOA HUMANA DA BIOÉTICA PERSONALISTA (PERSONALISMO ONTOLOGICA- MENTE FUNDADO)
}

\author{
The human person concept within \\ personalistic bioethics (Ontologically \\ based personalism)
}

\section{Dalton Luiz de Paula Ramos ${ }^{[a]}$, Maria Carolina Lucato ${ }^{[b]}$}

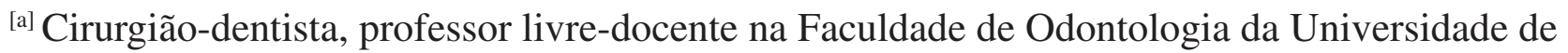
São Paulo (USP), membro da Pontifícia Academia para a Vida, do Vaticano, São Paulo, SP Brasil, e-mail: dalton@usp.br

${ }^{[b]}$ Cirurgiã-dentista; Mestre e Doutoranda em Ciências Odontológicas, com área de concentração em Odontologia Social, pela Faculdade de Odontologia da Universidade de São Paulo, com estágio de Doutorado no Istituto di Bioetica da Università Cattolica Del Sacro Cuore Roma, Curitiba, PR - Brasil, e-mail: mclucato@usp.br

\section{Resumo}

A bioética é uma ciência que surgiu no início da década de 1970, nos Estados Unidos, com objetivo de criar uma "ponte" entre a ciência biológica e a área dos valores. No Brasil, a bioética chega, efetivamente, em 1995, a partir da fundação da Sociedade Brasileira de Bioética e da promulgação da Resolução 196/96 do Conselho Nacional de Saúde, que regulamenta a 
pesquisa com seres humanos no país. A bioética possui vários modelos e dentre eles está o Personalismo Ontologicamente Fundado, criado por Elio Sgreccia. Essa linha de pensamento se funda na pessoa humana, ou seja, a pessoa deve ser o critério de avaliação frente a um dilema bioético. Toda pessoa humana é unitotalidade, dotada de uma dignidade. Ela é formada pelas dimensões física, psíquica, social, moral e espiritual. Esse modelo considera que toda vida humana tem início com a fecundação e fim com a morte natural. No presente trabalho, procurou-se demonstrar o conceito de pessoa em relação ao início da vida humana na perspectiva da bioética personalista. É preciso fazer com que a comunidade bioética brasileira conheça esse conceito de pessoa humana, tendo como critério de juízo a própria realidade, e utilize sua experiência de "pessoa" nos momentos em que seja necessário decidir sobre as intervenções que se faz sobre a vida.

Palavras-chave: Bioética. Bioética personalista. Personalismo ontologicamente fundado. Pessoa humana. Início da vida.

\section{Abstract}

Bioethics is a science that emerged in the beginning of the 70's in the U.S. by aiming to create a new "connection" between biologic science and values. Bioethics effectively arrived in Brazil in 1995, with the foundation of the Sociedade Brasileira de Bioética (Brazilian Bioethics Society) and the publication of Decree 196/96 by the National Health Council, which rules over research with human beings in the country. Bioethics presents several models, wherein the Ontologically Based Personalism as created by Elio Sgreccia can be found. This train of thought is based on the human person, i.e. the person needs to be the assessment criteria before a bioethical dilemma. Every human person is a unitotality who is endowed with dignity. It is formed by physical, psychic, social, moral and spiritual dimensions. This model considers that all forms of human life begin upon conception and end up with natural death. This article shows the human person concept referring to the beginning of life on a personalistic bioethics's view. It is necessary that the Brazilian bioethical community become acquainted with the concept of the person as resumed by the Ontologically Based 
Personalism, by having our own reality as judgment criteria, as well as using this experience of "person" when it is necessary to take decisions in regard to life.

Keywords: Bioethics. Personalistic bioethics. Ontologically based personalism. Human person. Beginning of life.

\section{INTRODUÇÃO}

A bioética como disciplina, com estatuto epistemológico próprio, surge no início da década de 1970, nos Estados Unidos, através da criação desse vocábulo como neologismo. Isso aconteceu contemporaneamente a partir de dois estudiosos, o oncologista Van Renssealer Potter e o médico obstetra André Helleghers. O primeiro procurou, através de um estudo intitulado Bioetichs - a brigde to the future, ligar (com uma ponte) duas culturas que até então, segundo ele, estavam caminhando em vias paralelas - a científica e a cultural, ou dos valores. A bioética de Potter nos remete às intervenções do homem sobre a vida, sua e da natureza. Já Helleghers preocupava-se com as intervenções da ciência sobre a saúde do homem.

A partir daí, outros estudos foram realizados e foi criado um primeiro modelo de bioética, que procurou orientar uma forma de conduta diante de dilemas éticos, principalmente na área médica, com a criação de quatro princípios - autonomia, beneficência, não-maleficência e justiça. Esse é o modelo principialista.

Outros modelos foram desenvolvidos em diversos países, e no Brasil a bioética chega aproximadamente em 1995. Nesse período foi criada a Sociedade Brasileira de Bioética, que marca essa entrada, em conjunto com a promulgação da Resolução 196/96 do Conselho Nacional de Saúde, que passa a regulamentar a experimentação com seres humanos no País. Essa resolução tem como base o modelo bioético principialista e seus princípios.

No entanto, apesar de moralmente válidos, e de serem parte do ponto de início da bioética, esses princípios foram muito criticados por parecerem insuficientes para a solução de grandes dilemas.

Em um encontro internacional sobre "As raízes da Bioética”, na Itália, em 1996, um dos pensadores desse modelo afirmou que, apesar das críticas, 
via nele um sistema forte e um ponto de partida. E é verdade. Mas hoje, em um momento cultural diferente, é preciso considerar outros aspectos.

Para que as ações bioéticas sejam totalizantes, e não redutivas, uma resposta pode ser encontrada no Personalismo Ontologicamente Fundado. Esse modelo bioético surgiu na Itália, mais precisamente no Istituto de Bioetica da Università Cattolica Del Sacro Cuore, em Roma, a partir da obra de seu pensador, Elio Sgreccia, fundador desse centro de excelência. O Personalismo Ontologicamente Fundado possui como fundamentação, como ponto de partida e como valor de referência para todas as decisões bioéticas a pessoa humana.

Segundo Sgreccia, a pessoa humana é uma unitotalidade, ou seja, unidade de corpo e espírito; e uma totalidade porque deve ser considerada em todas as suas dimensões (física, psíquica, espiritual, social e moral). Assim, antes de serem considerados princípios ou normas de ação, é preciso que olhemos para um fundamento, para o lugar de onde deve surgir a solução de um dilema bioético - a pessoa humana.

\section{O conceito de pessoa do Personalismo Ontologicamente Fundado}

Sgreccia diz que a bioética não pode ser concebida a partir de opiniões sobre posições éticas já existentes na sociedade, mas deve sugerir valores de referência próprios e linhas de escolha operativas, para fornecer "respostas objetivas sobre critérios racionalmente válidos" (SGRECCIA, 2002, p. 56).

Já em relação ao personalismo, o autor afirma que o personalismo ontológico não nega a relevância da subjetividade relacional e da consciência, mas sublinha como fundamento uma existência e uma essência estabelecidas na unidade corpo-espírito (SGRECCIA, 2002).

O modelo ético elaborado a partir do personalismo pretende promover a verdade plena sobre o homem. Por isso, uma reflexão bioética que quer permanecer humana e humanizante deve, ao elaborar seus princípios morais, partir do homem como pessoa - a pessoa humana é o valor fundante, transcendente e normativo, seja da reflexão ética, seja da prática que deseja se manter plenamente humana e moral (FRATTALLONE, 2004, p. 858-859).

O Personalismo Ontologicamente Fundado é uma linha da bioética que parte da pessoa (persona) como ponto de partida, com finalidade no 
reconhecimento da pessoa, de sua identidade e de sua essência. Esse reconhecimento tem como desdobramento o respeito à dignidade da pessoa humana (RAMOS, 2002).

O modelo bioético personalista propõe, então, uma antropologia de referência - a base para o juízo bioético - que busca entender o homem em sua essência, em sua verdade, em sua natureza, em sua unidade, em sua totalidade. E procura ainda ser um "personalismo realista", já que procura olhar todos os aspectos da realidade, ou seja, a totalidade dos fatos envolvidos (RAMOS, 2002).

A bioética personalista é, enfim, uma reflexão que afronta as questões éticas referentes à vida humana através de uma perspectiva que reconhece o ser e a dignidade da pessoa como valores absolutos e, consequentemente, põe como primum principium o respeito incondicional de sua inviolabilidade e a tutela de sua livre expressão, a partir dos direitos humanos (PAULA, 2004, p. 269-270). E essa deve ser considerada a norma personalista.

Essa visão do homem não só não se fecha à ciência, mas estimula a pesquisa e a experimentação, fornecendo às mesmas os critérios de humanização. De fato, se a pessoa como valor fundamental permanece no centro de qualquer interesse, é bom tudo o que a cura, que a protege ou a faz amadurecer; e é ruim quando a degrada, quando a instrumentaliza ou a destrói (FRATTALLONE, 2004, p. 358).

\section{O conceito de pessoa no Personalismo Ontologicamente Fundado}

O personalismo ontológico coloca como fundamento da bioética o conceito de pessoa. "É unânime a atribuição de significado do termo a um valor" (PALAZZANI, 1993, p. 52). A pessoa se converte em um filtro para a determinação da licitude ou ilicitude da intervenção sobre a vida:

A tradição personalista aprofunda suas raízes na própria razão do homem e no coração de sua liberdade: o homem é pessoa porque é o único ser em que a vida se torna capaz de reflexão sobre si, de autodeterminação; é o único ser vivo que tem a capacidade de captar e descobrir o sentido das coisas, e de dar sentido às suas expressões e à sua linguagem consciente (SGRECCIA, 2002, p. 79). 
A pessoa, aqui, é considerada segundo define Boécio - o tradutor latino de Aristóteles que cria grande parte da filosofia moderna (V e VI séculos): rationalis naturae individua substancia. De um lado ele precisa que a natureza da pessoa é racional, ou seja, espiritual, o que permite compreender que esse conceito se dá seja à pessoa divina, seja à pessoa humana; por outro lado, ele afirma que se trata de uma substância individual, isto é, concreta, subsistente em si mesma (BERTI, 1992, p. 47-48). No homem, a personalidade existe como individualidade, formada por um corpo animado que é estruturado no espírito. Em todo homem, em toda pessoa humana, o mundo adquire sentido: "a pessoa humana é uma unidade; um todo, e não uma parte de um todo" (SGRECCIA, 2002, p. 79).

A "substancialidade" da pessoa indica o ato de ser em si mesmo, é a presença de um substrato ontológico que ultrapassa o sentido de uma mera agregação de partes; a "individualidade" especifica a distinção de um ser de todos os outros seres (código genético); a "racionalidade" se refere a uma característica essencial do homem, independentemente da capacidade atual de seu exercício. Isso nos leva à conclusão de que o homem é pessoa pelo simples fato de ser um "ser humano" (PALAZZANI, 1993, p. 53)

Possenti (2006) escreve que, como sujeito substancial de natureza espiritual, dotado de inteligência, liberdade, autoconsciência e interioridade, a pessoa vive a abertura à totalidade do ser, segundo a capacidade da mesma de colocar-se em relação intencional com todas as coisas. Cada pessoa vive de modo original a sua relação com o universo, exprimindo características livres e criativas, projetando linguagens sempre novas:

Essa si presenta sopratutto come um centro di unificazione dinamica che procede dall'interno, un'unità che dura nel tempo al di sotto tutti i cambiamenti e al di là dei flussi psicologiche, della molteplicità delle sensazioni, dello sparpagliamento temporale e spaziale dell'io (POSSENTI, 2006, p. 26).

O autor conclui dizendo que a pessoa vale como totalidade, nunca é uma parte.

A pessoa é um ser relacional. Para o personalismo, o "entrar em relação" emerge da análise da relação do indivíduo com as coisas e com a sociedade. A relação "eu-tu" é aquela que constitui e revela a pessoa. O Personalismo Ontologicamente Fundado diz que, desde o primeiro instante da cada existência humana, essa relação ontológica por meio da qual é constituída

Rev. Pistis Prax., Teol. Pastor., Curitiba, v. 2, n. 1, p. 57-75, jan./jun. 2010 
uma ligação com um "tu" é aquela em que se descobre a relação com um "eu" independente de cada um. Assim a relação "eu-tu" é extrínseca à pessoa, é um espaço criado para a ligação interpessoal. O autêntico diálogo interpessoal vai além da comunicação verbal, chegando à "intimidade inegável da verdade do eu" (FRATTALLONE, 2004, p. 358-359).

A pessoa, segundo o mesmo autor, é também corporeidade. É esse elemento que delimita com mais precisão o horizonte hermenêutico no interior da reflexão ética e científica sobre o homem, entrando, assim, em diálogo para resolver problemas comuns de origem teórica e prática. A corporeidade da pessoa é a primeira revelação do seu "ser no mundo" (e permanece sendo), e é o fundamento biológico da unicidade e da originalidade de cada pessoa. A genética, em particular, revela como o patrimônio genético de um indivíduo é ao mesmo tempo totalmente dependente dos códigos genéticos de seus pais, e também totalmente único e irrepetível.

A dimensão corpórea da pessoa revela, ainda, sua historicidade. Isso porque há a renovação das células corpóreas (um dado biológico indiscutível). E enquanto a pessoa vive essa historicidade biológica, realiza sua transcendência espiritual, que "fica além dos adventos de seu mundo circundante" - e essa é a ambivalência da pessoa (FRATTALLONE, 2004, p. 359).

O mesmo autor diz que a corporeidade revela como o indivíduo organiza o seu modo de agir e reagir frente ao mundo que o circunda (no sentido sensorial). O "ser-relação" de cada pessoa desenvolve seu valor existencial na organização de suas próprias sensações. É, sobretudo, no momento da relação (interior ou exterior) que se pode constatar uma intervenção original e criativa da pessoa.

A definição de Boécio inclui o aspecto corpóreo-biológico-genético da pessoa. A porção corpórea não pode ser colocada de lado para que se considerem somente a autoconsciência, a racionalidade e o juízo moral como elementos constitutivos da pessoa. A pessoa é unidade de corpo e espírito, e não pode ser privada nem do componente biológico, nem daquele que diz respeito ao espírito. É um equívoco considerar o elemento biológico como acidental e sem influência, bem como reduzir o homem somente à sua porção biológica (POSSENTI, 2006, p. 25).

A pessoa é pessoa e não se torna pessoa quando manifesta determinados comportamentos. A pessoa não pode ser reduzida à manifestação de determinadas funções ou operações (PALAZZANI, 1993, p. 53). Segundo a mesma autora, o personalismo ontológico admite que todos os seres humanos 
são pessoas: já é pessoa o zigoto, o embrião, o feto, o recém-nascido, a criança - já que possuem elementos que, desenvolvidos na ausência de obstáculos, conduzirão à atuação completa da pessoa. E, ao mesmo tempo, é pessoa o ancião, o enfermo em coma, o paciente terminal - que enquanto seres humanos podem exercer algumas funções. É o "completo arco biológico da vida humana".

Diante de qualquer reflexão racional em relação à bioética personalista, portanto, está a pessoa humana se apresentando como valor de referência. As diversas áreas da ciência, a medicina, a economia, a ética, têm como destinação o homem, que deve ser considerado na plenitude de seu valor (SGRECCIA, 2007, p .70-73).

Esse personalismo não deve ser confundido com o individualismo subjetivista. Esse último seria uma concepção na qual se mantém que a constituição da pessoa se encontra exclusivamente em sua capacidade de autodecisão e de escolha (SGRECCIA, 2007; RAMOS, 2002). "O personalismo clássico (de tipo realista e tomista) sem negar a capacidade de escolha, afirma principalmente um estatuto ontológico da pessoa" (SGRECCIA, 2007, p. 72), sendo a pessoa um corpo espiritualizado que vale pelo que é e não somente pelas escolhas que faz. Este personalismo vê a pessoa como unitotalidade - de corpo e espírito - em todas as suas dimensões - a física, a psicológica, a social, a espiritual.

\section{O conceito de pessoa humana e o início da vida humana}

Uma das principais perguntas existentes no debate bioético é a de quando se inicia a vida humana. Trata-se de uma questão cuja reposta poderia ser, à primeira vista, facilmente respondida: a vida do ser humano tem início, biogeneticamente, no momento da fecundação. Este é um dado científico que deveria ser considerado indiscutível. Se existem discussões sobre a definição filosófica de pessoa e também sobre a identificação do início da vida pessoal, parece impossível que haja qualquer dúvida a respeito do início da vida biogenética do ser humano, já que, sendo o ser humano espécie vivente do Homo sapiens, o início de sua vida deveria coincidir com a união dos gametas humanos - masculino e feminino (PALAZZANI, 1996, p. 41-42).

No entanto, as descobertas recentes em relação à embriologia, relativas às primeiras fases da formação do zigoto humano, rendem essa problemática a identificação da origem desta vida. E é essa situação que caracteriza o debate

Rev. Pistis Prax., Teol. Pastor., Curitiba, v. 2, n. 1, p. 57-75, jan./jun. 2010 
científico atual em bioética, e nos leva ao obscuro significado do ser humano, e mais ainda, do conceito de pessoa humana. E isso envolve também a filosofia do referido conceito, já que não se pode interrogar sobre o conceito de pessoa sem antes saber quando o ser humano tem início, e se esse início corresponde ao princípio da vida da pessoa (PALAZZANI, 1996, p. 42).

$O$ fato é que, no Brasil, esse dado ganhou grande evidência no debate bioético no ano de 2007, quando a Lei de Biossegurança, promulgada em 2005, regulamentou a utilização de embriões congelados há mais de três anos em clínicas de fertilização in vitro em pesquisas com células-tronco, gerando uma série de audiências no Supremo Tribunal Federal, a fim de se determinar o início da vida válido juridicamente no País (BRASIL, 2005).

O posicionamento do Personalismo Ontologicamente Fundado é claro: cada gameta contém metade das informações genéticas necessárias para que se torne um embrião. Por isso, quando um óvulo e um espermatozoide se unem, seja natural ou artificialmente, tornam-se um embrião (assim alterando substancialmente sua natureza, no sentido de tornar-se qualquer coisa diferente de si). Ou seja, o ser humano se constitui biológica e geneticamente no momento da fertilização (quando há a formação de uma nova entidade biológica que carrega um projeto individualizado). A fertilização não é um evento simples, mas um processo dinâmico e complexo que acontece com o tempo - do momento da penetração do espermatozoide no óvulo (quando as membranas dessas duas células se abrem e unem seus materiais genéticos, iniciando uma intensa atividade de interação) até o estágio da singamia, que é o momento da fusão completa de todos os cromossomos das células geminais. Existe desde aí, isto é, desde a penetração do espermatozoide no óvulo, uma nova capacidade de organização de todas as fases sucessivas da vida humana. E esse ser "processo" não anula a individualidade e a identidade ontológica daquele ente que faz parte do evento - o processo indica a sucessão sequencial de desenvolvimento desse ente no tempo, dinâmica e progressivamente (PALAZZANI, 1996, p. 44-53; SGRECCIA, 2007, p. 546-548; SUTTON, 1994, p. 478-479).

E é precisamente essa nova constituição genética que individualiza claramente e define o zigoto, isto é, torna-o um sujeito com sua própria existência e com suas características próprias, que o distinguem de qualquer outro ser (SERRA, 1987, p. 93).

De fato, a fertilização constitui um evento, ou um processo, peculiar, e é essa mesma peculiaridade que determina sua relevância axiológica e normativa. 
A formação do zigoto constitui o início de uma "nova entidade qualitativamente nova", diferente de tudo o que a precede. Com o encontro dos dois gametas humanos (feminino e masculino) se compõe uma identidade genética e biológica humana, radicalmente nova, única e irrepetível; e cada modificação genética nesse processo contínuo é de "tipo quantitativo", ou seja, "progressiva, gradual e coordenada". Esse novo genoma identifica o embrião como biologicamente humano e, mesmo que com apenas uma célula, especifica sua individualidade. Portanto a relevância ética desse processo, se reconhecida em qualquer outro momento sucessivo e isolado desta continuidade ininterrupta (cada eventual, intencional ou acidental interrupção dele causa a morte do organismo), deve ser considerada arbitrária (SGRECCIA, 2007, p. 546; PALAZZANI, 1996, p. 47).

Esse projeto - o zigoto - se autocontrola (o que determina uma unidade na orientação de seu desenvolvimento) e possui em sua autonomia a unidade permanente do sujeito através de todas as diferenciações de tecidos e órgãos que irão aparecer gradualmente. Do ponto de vista biológico, "o novo aparato genético representa o centro de unificação de todos os processos e funções vitais que se desenvolvem no novo ser (SERRA, 1987, p. 96).

Assim, esse novo genoma não é estático e não depende dos órgãos fisiológicos da mãe para ser executado (exemplo disso é que o embrião pode ser fertilizado em ambiente extrauterino). É um novo projeto que se constrói e é seu ator principal. Esse processo, segundo Sgreccia (2007, p. 546-550), é coordenado (com sucessão de atividades moleculares e celulares sob controle do próprio embrião), contínuo (pois após a fertilização procede sem interrupção, se são verificadas condições exigidas para tal) e gradual (a formação final do organismo ocorre a partir das passagens mais simples - unicelular - até as mais complexas).

Para o ser humano vale a "lei ontogenética", que determina o desenvolvimento de cada ser derivado de reprodução através de gametas:

$\mathrm{Na}$ ontogênese humana o homem que se forma através de uma série de fases, das quais a precedente é sempre premissa para a que se segue; é um homem determinado, que se forma através de um programa genoma, que é um projeto no qual a ontogênese é ativamente controlada (SERRA, 1987. p. 96-97).

Sobre esse assunto, Azevêdo (1998) diz que a genética demonstra que todas as células somáticas de um indivíduo, sem exceção, possuem o mesmo genótipo, ou seja, 46 cromossomos dispostos em pares. Em cada célula somática

Rev. Pistis Prax., Teol. Pastor., Curitiba, v. 2, n. 1, p. 57-75, jan./jun. 2010 
do ser humano, em qualquer estágio de seu desenvolvimento, de qualquer tecido ou órgão, permanece a mesma informação genética que se formou na fertilização. "Assim, a informação genética tal qual se formou no zigoto é a mesma presente em cada célula somática durante toda a vida”. Fica evidente que não existem diferenças entre a composição genética do recém-concebido e do adulto, isto é, o recém-concebido "é um organismo informacional completo" (AZEVEDO, 1998, p. 115-116).

O DNA de todas as células permanece o mesmo, independente do grande número de multiplicações celulares experimentados por nosso organismo desde o estágio unicelular pós-fecundação até a morte por extrema idade. A mesma autora diz que organismo humano é formado por trilhões de células, e para que elas adquiram a forma e a função do organismo humano só existe uma maneira: começar a partir de uma célula, que vai se multiplicando. Inclusive, os avanços em reprodução humana demonstram que, invariavelmente, o ponto inicial desse processo é a fertilização. Diz, também que a reprodução humana, seja ela natural ou in vitro, não apresenta começos alternativos: inicia-se invariavelmente com uma única célula. Dessa forma, o zigoto é o princípio da vida humana. E conclui dizendo que o embrião é autossuficiente sobre seu próprio desenvolvimento e que a afirmação de que ele é parte do corpo da mãe não tem fundamento biológico (AZEVEDO, 1998).

Da fertilização, então, surge o zigoto, que é na realidade um novo ser humano que atua, segundo a lei da ontogênese, seguindo as potencialidades que traz consigo em seu genoma. Em seguida, esse embrião adquire a figura humana com a qual se está mais familiarizado. Por isso, Serra (1987, p. 97) afirma que, sem possibilidade de erros, estamos sempre na frente de um mesmo sujeito, desde o primeiro momento em que se constitui sujeito até o fim de seu ciclo vital. O zigoto e o feto são "ser humano" em fase de desenvolvimento; mesmo um recém-nascido é um sujeito humano, uma pessoa em fase de desenvolvimento, e ninguém ousaria dizer que ele não o é. E o recém-nascido é o zigoto dos anteriores nove meses, meses que o levaram a se desenvolver para poder respirar e alimentar-se fora do ventre materno.

Outro fator que evidencia o que foi escrito até agora é a terapia gênica. Segundo Azevedo (1998, p. 117-118), essa terapia consiste em usar genes no lugar de drogas para o tratamento de doenças genéticas e não genéticas. A autora mostra que a proposta dessa terapia "implica o reconhecimento de uma vida em curso à qual se oferta um tratamento. A oferta terapêutica não teria 
sentido caso não houvesse uma pessoa a tratar" (AZEVEDO, 1998, p. 117-118). Observa-se que a finalidade aqui é tratar a vida existente no embrião e não as células embrionárias em si. A pessoa humana é considerada o mesmo que vida humana, e ocorre a partir da fecundação, indo até a morte natural. "A existência de diferentes etapas na vida de uma pessoa não significa que, para diferentes etapas, possamos falar em diferentes graus de plenitude" (RAMOS; SILVA; CALDATO, 2009, p. 52).

\section{Teorias que negam a fertilização como início da vida humana}

Os debates relacionados à consideração do início da vida humana coincidente com qualquer fase que sucede a fertilização são baseados, principalmente, em reflexões filosóficas, antropológicas, éticas e jurídicas (PALAZZANI, 1996, p. 53).

Existem teorias que querem demonstrar que a vida humana tem início somente depois da singamia, ou ainda depois do princípio da formação do sistema nervoso central. Nesse sentido, sem a precisão de uma delimitação, nega-se a presença do ser humano e, consequentemente, da pessoa humana. Assim se justificaria, dentre outras coisas, a experimentação não terapêutica com embriões, ao menos antes da singamia, ou seja, nas primeiras horas de sua formação (PALAZZANI, 1996, p. 53).

Serão apresentadas aqui algumas teorias que negam que a vida humana tenha início no momento da fecundação. São elas:

\section{a) Teoria da relação}

A partir desta teoria, considera-se ser humano o embrião que se implanta na parede uterina, fato que pode ocorrer do $5^{\circ}$ ao $14^{\circ}$ dias. A principal razão adotada para justificar a relevância desse fenômeno no reconhecimento da pessoa é a observação do início de uma estreita comunicação intercelular entre embrião e organismo materno. Nesse sentido, seriam necessárias, para a sobrevivência e evolução do embrião humano, as informações extrazigóticas provenientes da mãe (entendendo por essas informações apenas o suporte nutritivo). Portanto, o zigoto não possuiria todas as informações necessárias e 
suficientes para tornar-se pessoa. Então, no contexto de uma visão filosófica, essa teoria retém que a relação seja constitutiva da pessoa, sendo fato humano fundamental a comunicação, a presença de um outro; e considera que o embrião, antes do anidamento, é apenas um "amontoado de células", sem autonomia operativa (PALAZZANI, 1996, p. 53-56).

Revisando essa teoria, pode-se afirmar que é o genoma humano que possui a força prioritária para endereçar autonomamente o desenvolvimento do embrião em uma direção bem precisa. O programa genético tem início já na fecundação, e a continuidade do processo depende de alguns fatores externos, como o aporte da mãe. Por isso, é evidente que a autonomia do embrião deve ser considerada como capacidade de dirigir o próprio processo vital; não existe uma completa dependência do exterior. Palazzani (1996, p. 56-57) afirma que mesmo um sujeito adulto necessita do ambiente que o circunda. A relação com a mãe é necessária para o desenvolvimento, mas não constitui ontologicamente o embrião (já antes da implantação se instaura uma relação bioquímica entre embrião e mãe).

Portanto, do ponto de vista filosófico, se é verdade que a relação é um elemento indispensável para o ser da pessoa, é certo dizer que ela não constitui ontologicamente o sujeito, mas, vice-versa, é a realidade do sujeito que torna possível a relação - não existe relação se não existe um ser se relaciona com o outro (SGRECCIA, 2007, p. 564).

\section{b) Teoria da individualidade humana - a perda da totipotência}

No âmbito da conceituação de pessoa humana, a delimitação do confim de relevância ético-jurídica a partir da formação da linha primitiva, ou seja, a partir do $14^{\circ}$ dia após a fecundação, é mais notável e mais discutida na literatura da bioética. E essa notoriedade se deve ao Relatório Warnock, elaborado em 1984 pelo Committee of Inquiry into Human fertilization and Embryology, do governo inglês. Esse documento limitou o $14^{\circ}$ dia como limite para pesquisas com embriões, e essa demarcação foi adotada não somente na Inglaterra, mas em vários países da Europa (SUTTON, 1994, p. 475).

O ponto crucial para a identificação empírica da pessoa, segundo o Relatório Warnock, é a verificação da individualidade do embrião. Considerase primeiramente a "unidade espacial", ou seja, é indivíduo um ente concreto separado de outra entidade (existente em si, independente). Um segundo critério 
é a "unidade espaço-temporal", pela qual um ente é individual quando permanece ele mesmo (numericamente) na sucessão do tempo - e até o $14^{\circ}$ dia é possível ocorrer a bipartição ou a fusão. O terceiro critério é o de "diferenciação e determinação" das partes e de "organização e direção" - um ente é um indivíduo se possui em si mesmo o princípio do movimento e a capacidade ativa de se autodirigir e manter o desenvolvimento do processo vital. Por isso, segundo esse relatório, não se pode reconhecer a presença de um indivíduo humano pelo menos até o fim do $14^{\circ}$ dia. Esse texto diz que, antes disso, o embrião é somente um "amontoado de células", ou uma colônia de células não diferenciadas, fechadas na zona pelúcida, e que esse é um período de preparação para a formação do ser humano (SGRECCIA, 2007, p. 552; PALAZZANI, 1996, p. 61-68). Os autores do Relatório Warnock nomearam essa fase inicial com o termo "preembrião" (SGRECCIA, 2007, p. 554).

Quanto a esse argumento, pode-se dizer que uma observação atenta do embrião nessa fase inicial mostra a estreita inteiração entre suas diversas células, que constituem um organismo multicelular unitário (PALAZZANI, 1996, p. 70).

A linha embrionária representa um dos pontos de chegada de um processo sequencial e ordenado que tem início no momento em que se forma o zigoto. No período de preparação dos sistemas do embrião, as células que darão origem à linha primitiva já estão lá. Seria incorreto admitir que a presença da linha primitiva divide o processo - do zigoto à formação da linha e dessa em diante - pois, se assim fosse, os processos seriam individuais e não teriam nenhuma correlação entre si. Essa linha não surge de improviso, nem aparece através de estímulos externos, e também não está separada do todo processual que começa a se desenvolver a partir da fertilização: é um produto desse mesmo processo (SERRA, 1987, p. 100).

Mas o fato mais relevante em relação a essa teoria é que até o $14^{\circ}$ dia o embrião pode unir-se a outro (hibridação) ou ainda se dividir em dois (divisão gemelar). Essa ideia faz com que, de acordo com o relatório, a aplicação do conceito de pessoa desde a fertilização seja revisto, já que até esse período o embrião é considerado apenas uma individualidade humana biogenética: o zigoto seria um ser humano individual no sentido biológico, e somente depois do $14^{\circ}$ dia após a fertilização (até quando seria considerado um indivíduo em potencial no sentido filosófico), uma individualidade humana ontológica, ou melhor, uma pessoa no sentido filosófico. $\mathrm{E}$ isso se deve ao fato de que o embrião em suas duas primeiras semanas de vida é totipotente, isto é, tem 
potência para se unir a outro embrião, ou se dividir em dois, o que descaracterizaria sua individualidade, e também sua continuidade no tempo, ambos propostos pelo relatório. Assim, "as duas primeiras semanas do desenvolvimento embrionário não seria um desenvolvimento do indivíduo humano, mas no indivíduo humano" (PALAZZANI, 1996, p. 71).

Nesse sentido, o Personalismo Ontologicamente Fundado argumenta dizendo que até o embrião originário, que passa a não existir mais no momento em que origina dois indivíduos, é contínuo ontologicamente. Trata-se de um ciclo de vida extremamente breve, mas um ciclo vital contínuo de um indivíduo singular, biológica e ontologicamente determinado. O momento da divisão é causado por uma interferência no projeto. Então, mesmo o embrião originário seria uma vida humana em início, mesmo que por tempo determinado e breve; não seria certamente o indivíduo que se tornaria adulto, mas o zigoto seria o mesmo indivíduo que surge dois ou mais dias após a fecundação (SGRECCIA, 2007, p. 550; PALAZZANI, 1996, p. 69-70).

Serra (1987, p. 102) utiliza uma analogia para exemplificar o caso da divisão gemelar: a reprodução agâmica, em que algo similar acontece - existe um indivíduo, que pode ser uma hidra, constituída de algumas células. Num certo momento, dessa hidra se forma uma célula - a gema - que se destaca para dar início à formação de outra hidra; o que não tira a individualidade e a verdadeira unidade daquela na qual teve início o processo. Assim, o zigoto humano pode contribuir à origem de um novo indivíduo humano, mesmo depois de ter percorrido certo caminho.

Já no fenômeno da hibridação, também não se pode negar o fato da existência de um projeto bem definido em cada uma das células fecundadas, que poderia se desenvolver de maneira autônoma como dois zigotos se não fossem perturbados por causas externas (SGRECCIA, 2007, p. 556).

O fato de que nessas primeiríssimas fases se possam verificar eventos extrínsecos ou patológicos pelos quais se originem, de uma célula fecundada, dois gêmeos homozigotos, ou que dois óvulos fecundados se unam em um só (hibridação), ou ainda que se verifiquem interrupções ou miniabortos, tudo isso não muda a natureza e a qualidade intrínseca do genoma e de seu dinamismo individualizado (SGRECCIA, 2002, p. 346).

O mesmo autor diz que o embrião possui capacidade real de ativar todas as atividades relativas a um ser humano adulto. Essa capacidade se 
RAMOS, D. L. P.; LUCATO, M. C.

encontra na essência da individualidade humana. Nessa individualidade o corpo é informado e estruturado pelo espírito e, por isso, "não se pode afirmar a distinção ontológica entre o indivíduo humano [...] - qualquer que seja o estádio de desenvolvimento a partir da fecundação - e pessoa humana - qualquer que seja o estado de amadurecimento intelectual" (SGRECCIA, 2002, p. 124).

\section{CONCLUSÃO}

O conceito de pessoa é fundamental no âmbito da bioética, já que muitos dilemas da área são resolvidos com base na identificação de um ser humano como sendo ou não pessoa.

E muitas são as teorias para definir a pessoa humana, em especial quando tratamos os estágios iniciais da vida humana. A discussão sobre o início da vida humana foi intensa no Brasil no ano de 2007, após a promulgação da Lei de Biossegurança no País, que regulamenta os transgênicos e a experimentação com células-tronco embrionárias (de embriões congelados há mais de três anos em clínicas de fertilização in vitro). $\mathrm{O}$ ex-procurador da república, Carlos Fonteles, entendeu que essa legislação fere o direito à vida, garantido a todas as pessoas pela Constituição Brasileira, e por isso, protocolou uma ADIn (Ação Direta de Inconstitucionalidade) contra o artigo que regulamenta a experimentação com embriões. Assim, alguns cientistas foram convidados a participar de uma reunião no Supremo Tribunal Federal para que houvesse a elucidação, aos ministros, de conceitos referentes ao início da vida. Alguns cientistas se posicionaram contra a experimentação com embriões, outros em favor da mesma. E em 2008, o Supremo Tribunal Federal julgou constitucional a Lei de Biossegurança, permitindo a realização de tais pesquisas.

Assim, em todo esse período o início da vida tornou-se tema frequente na mídia, trazendo à tona manifestações dos mais variados tipos. Não entrando no mérito da questão da efetividade das experimentações com células-tronco embrionárias, o Personalismo Ontologicamente Fundado (bioética personalista) entende que todo embrião é vida humana em início.

A ciência nos mostra que através da união entre o óvulo e o espermatozoide tem início uma nova entidade humana, formada por 23 cromossomos da mãe e 23 do pai, não sendo, portanto, parte de nenhum dos dois genitores, mas um indivíduo humano único e irrepetível. A partir desse 
momento - fecundação - começa uma série de processos que desencadeiam no desenvolvimento de um bebê, que se desenvolverá e será uma criança e, depois, um adulto. Se esses processos não sofrerem uma parada repentina, o desenvolvimento é contínuo e acontece até o fim da vida desse indivíduo.

A compreensão desse conceito nos faz perceber que essa entidade, criada na fecundação, é uma nova vida humana. Admitir que a vida tem início na fecundação é considerar antiéticos procedimentos como o aborto e a experimentação com embriões. Toda vida humana tem o direito de ser vivida. Uma vez que não haja interrupção, o desenvolvimento de um embrião vai terminar no nascimento de um bebê. Quer dizer, não termina nesse momento. Se a vida segue seu curso natural, esse bebê se torna criança, adolescente e adulto.

As técnicas de fertilização in vitro não são regulamentadas em nosso país (existe somente uma resolução do Conselho Federal de Medicina que dispõe sobre esses procedimentos). Na Itália existe a "Legge 40", lei de 2004 que regulamenta essas técnicas e que traz como base a proteção do embrião, da seguinte maneira: três embriões são produzidos e três são implantados. Não existe margem para embriões excedentes, evitando seu uso em experimentações de células-tronco e as grandes discussões éticas acerca do tema.

A autonomia de uma mãe nos casos de aborto é outro aspecto de discussão bastante evidente no que concerne ao início da vida. Uma solução é ética quando os valores a serem discutidos são homogêneos entre si. Em confronto com uma vida humana, não se deve privilegiar a liberdade. É bom que lembremos que, como vida humana em início, o embrião não tem como fazer valer a sua autonomia. Além disso, uma vez que se age com liberdade, é preciso que se tenha responsabilidade. E, neste caso, a mãe, e também o pai, devem se responsabilizar sobre aquela nova vida humana.

A sociedade parece viver os dias de hoje inseridas em "meios de cultura" que procuram fazer com que somente um aspecto de nossas vidas seja considerado. Isso acontece no hedonismo (quando a maximização do prazer e a supressão da dor são valores absolutos, ou seja, quando a felicidade é um valor absoluto); no individualismo (quando o importante é a consideração das liberdades individuais, isto é, cada um deve fazer o que for melhor para si mesmo); e no utilitarismo (quando existe a busca pelo sucesso a qualquer custo, onde vale a relação custo-benefício). Todos desejam ser felizes, poder exercer suas liberdades e obter sucesso. Mas nenhuma dessas condições pode ser considerada absoluta, pois se assim fosse, seria como se vivêssemos 
RAMOS, D. L. P.; LUCATO, M. C.

anestesiados, sem os pés no chão. Isso porque a vida de toda pessoa contém também sofrimento, fracassos - afinal, ninguém é infalível. E também porque toda liberdade deve ser relacionada com a responsabilidade. Devemos viver enfrentando nossa realidade quando e como ela aparece, e para isso, utilizar uma base, um ponto de partida.

Por isso, ao considerar a pessoa humana como fundamento de um modelo ético, como na bioética personalista, se enfrenta a realidade com precisão, e partese dessa entidade (unidade de corpo-espírito) como parâmetro para ditar a prática da bioética. Assim, a dignidade de todo ser humano é certamente respeitada.

\section{AGRADECIMENTO}

À Coordenadoria de Aperfeiçoamento de Ensino Superior - CAPES, pela bolsa de estágio doutoral.

\section{REFERÊNCIAS}

AZEVEDO, E. S. Aborto: biologia e ética. Rev Med PUCRS, v. 8, n. 3, p. 114-122, 1998.

BERTI, E. et al. Persona e personalismo. Padova: Gregorina Libraria Editrice, 1992.

BRASIL. Lei n. 11.105, de 24 de março de 2005. Regulamenta os Incisos II, IV e V do parágrafo 1 do artigo 225 da constituição federal, estabelece normas de segurança e mecanismos de fiscalização de atividades que envolvam organismos geneticamente modificados - OGMe seus derivados, cria o Conselho Nacional de Biossegurança-CNBS, reestrutura a comissão tecnica nacional de biossegurança-CTNBIO, dispõe sobre a politica nacional de biossegurança - PNB, revoga a Lei 8.974, de 5 de janeiro de 1995, e a medida provisória 2.191-9, de 23 de agosto de 2001, e os artigos 5, 6, 7, 8, 9, 10 e 16 da lei 10.814, de 15 de dezembro de 2003, e dá outras providencias. Diário Oficial [da] República Federativa do Brasil, Brasília, DF, 28 mar. 2005. p. 1, 2005. Disponível em: http://www6.senado.gov.br/sicon/Lista Referencias.action?codigoBase=2\&codigoDocumento=250537>. Acesso em: 15 set. 2009.

FRATTALLONE, R. Persona. In: LEONE S.; PRINITERA, S. Nuovo dizionario di bioetica. Roma: Città Nuova Editrice, 2004. p. 856-863. 
PALAZANNI, L. Il concetto di persona umana tra bioética e diritto. Torino: Giapichelli, 1996.

. La fundamentación personalista en bioetica. Cuadernos de Bioética, v. 14, n. 2, p. 48-54, 1993.

PAULA, I. C. Il concetto di persona e la sua rilevanza assiologica: i principi della bioetica personalista. Medicina e Morale, n. 2, p. 265-278, 2004.

POSSENTI, V. Il principio-persona. Roma: Armando, 2006.

RAMOS, D. L. P. Fundamentos e princípios da bioética. Notandum, v. 9, 2002. Disponível em: <www.hottopos.com/notand9/dalton.htm>. Acesso em: 10 mar. 2008.

RAMOS, D. L. P.; SILVA, M. M. P.; CALDATO, M. C. F. A pessoa e a vida humana: um fundamento para a bioética. In: RAMOS, D. L. P. Bioética, pessoa e vida. São Caetano do Sul: Difusão, 2009. p. 39-56.

SERRA, A. Quando comincia um essere umano. In margine di un recente documento. In: SGRECCIA, E. Il dono della vita. Milano: Vita e Pensiero, 1987. p. 91-106.

SGRECCIA, E. Manual de bioética I: fundamentos e ética biomédica. 2. ed. São Paulo: Loyola, 2002.

Manuale di bioetica I: fondamenti ed etica biomedica. Milano: Vita e Pensiero, 2007.

SUTTON, A. Ten years after Warnock Report: is the human neo-conceptus a person? Medicina e Morale, n. 3, p. 475-490, 1994.

Recebido: 20/10/2009

Received: 10/20/2009

Aprovado: 30/10/2009

Approved: 10/30/2009 